\title{
PENERAPAN AZAS RUKUN, LARAS DAN PATUT DALAM PENYELESAIAN SENGKETAADAT \\ ( STUDI KASUS DI BANJAR ADAT AMBENGAN DENGAN BANJAR ADAT SEMANA KECAMATAN UBUD KABUPATEN GIANYAR PROVINSI BALI )
}

\author{
I Gusti Ngurah Dharma Laksana, S.H., M.Kn \\ Bagian Hukum dan Masyarakat Fakultas Hukum Universitas Udayana
}

\begin{abstract}
Lands play an important role in our life. It becomes part of people's life because lands are used to be the graveyards where the dead bodies are buried. The graveyard is also called as the 'final resting place.' As the role is very significant, especially in the life of customary village members in Bali, lands are often disputed among the members of one and other customary villages. The dispute becomes the object of many cases that ruins harmonious situation of native people in Bali. Take for example, the dispute that takes place in Banjar Adat Ambengan and Banjar Adat Semana Ubud District, Gianyar Regency and Bali Province. The problem to be solved is to investigate the causes of conflict as well as the implementation of land for peace, harmony, appropriateness and the parties involved in the settlement of the dispute. The investigation on the case that took place between the two customary villages was conducted through descriptive qualitative method supported by the case study approach. The finding showed that the dispute was settled by applying mediation method conducted through the meeting of the involved parties. It occurred several times with the principles of peace, harmony, and appropriateness to meet the society that live peacefully and harmoniously where people respect the existing customary law.
\end{abstract}

Key words : Peace, Harmony and Appropriateness, Settlement, Customary Village Dispute

\section{PENDAHULUAN}

Tanah mempunyai arti penting dalam kehidupan. Arti penting tanah selain dijadikan tempat tinggal juga merupakan sumber kehidupan dan tempat mencari nafkah. Selain itu tanah juga sebagai tempat bagi menguburkan orang-orang yang sudah meninggal (tempat peristirahatan terakhir). Mengingat tanah sangat penting bagi kehidupan manusia, sehingga tanah sering menjadi obyek sengketa dari orang-orang yang menginginkannya. Sengketa merupakan bagian dari konflik dalam dinamika kehidupan masyarakat yang semakin komplek, disebabkan adanya benturan kepentingan antara dua atau lebih subyek hukum yang berisikan tuntutan pemenuhan hak dan kewajiban.

Konflik mungkin pula menjadi sebab terjadinya perubahan sosial dan kebudayaan. Konflik terjadi antara individu dengan kelompok atau kelompok dengan kelompok. Keadaan demikian menimbulkan perubahan-berubahan tertentu dalam masyarakat. Pertentangan antar kelompok mungkin terjadi antara generasi tua dengan generasi muda. Pertentangan-pertentangan tersebut kerap terjadi, apalagi pada masyarakat yang sedang berkembang dari tahap tradisional ke tahap modern. Generasi muda yang belum terbentuk kepribadiannya lebih mudah menerima unsur-unsur kebudayaan asing yang dalam beberapa hal mempunyai taraf yang lebih tinggi. Keadaan demikian menimbulkan perubahanperubahan tertentu dalam masyarakat. ${ }^{1}$

Timbulnnya konflik umumnya disebabkan oleh berbagai faktor 1) Konflik Data (Data Conflict), 2) Konflik Kepentingan (Interest Conflict), 3) Konflik Hubungan (Relationship Conflict), 4) Konflik Struktur (Structural 
Conflict), 5) Konflik Nilai (Value Conflict). ${ }^{2}$ Konflik merupakan suatu gejala yang melekat pada setiap masyarakat, dan setiap unsur dalam masyarakat memberikan sumbangan untuk terjadinya disintegrasi dalam wujud konflik. ${ }^{3}$

Mustahil untuk menghilangkan konflik dalam kehidupan masyarakat, namun yang terpenting bagaimana konflik mesti diarahkan kepada sesuatu yang bermanfaat bagi kepentingan dan kemajuan masyarakat. Dalam hubungan tersebut masyarakatlah yang mesti melakukan kontrol. Terjadinya konflik/sengketa semakin hari semakin bertambah banyak, baik yang sifatnya sederhana maupun yang bersifat kompleks. Sengketa yang banyak terjadi khususnya di Bali antara lain : sengketa tapal batas, pemekaran wilayah, perebutan Pura, pensertifikatan tanah adat, sengketa tanah kuburan.

Seperti halnya sengketa tanah kuburan yang terjadi di Banjar Adat Ambengan dengan Banjar Adat Semana Kecamatan Ubud Kabupaten Gianyar Provinsi Bali, sebenarnya hal seperti itu sangat disayangkan. Karena akan membawa dampak yang kurang baik, tidak saja menimbulkan keresahan bagi masyarakat sekitar (psikis) tetapi menimbulkan keresahan bagi masyarakat luas. Maka dari itulah diperlukan peran dan kerjasama semua pihak antara lain : para pihak yang bersengketa, pemerintah daerah, penegak hukum (dalam rangka mengamankan ketertiban umum), kesbang pol dan linmas, tokoh adat, tokoh agama, dan pihak-pihak yang terkait supaya sengketa tersebut tidak berkepanjangan.

Sebagaimana yang kita ketahui, bentuk penyelesaian sengketa dapat dilakukan dengan ada 2 (dua) cara, yaitu secara litigasi (pengadilan) dan non-litigasi (diluar pengadilan). Masing-masing penyelesaian sengketa memiliki kelebihan dan kekurangan, tergantung yang mana yang lebih disukai atau dianggap paling tepat oleh para pihak untuk menyelesaikan permasalahan yang sedang dihadapi. Masyarakat Bali dewasa ini dalam menyelesaikan sengketa, khususnya sengketa adat lebih mengutamakan penyelesaian dengan cara non-litigasi. Apalagijika sengketa melibatkan antar banjar adat maupun desa adat (sekarang desa pakraman). Apabila dalam kenyataannya tingkat keberhasilan menyelesaikan sengketa melalui mediasi yang mengarah pada win-win solusion sangat rendah sehingga perlu dicari faktor penyebabnya. Sepatutnya menyelesaikan suatu permasalahan yang berkaitan dengan tanah adat khususnya tanah kuburan, supaya penyelesaian persoalan tidak dengan cara-cara kekerasan (pengerusakan maupun penganiayaan), akan tetapi terlebih dahulu dimusyawarahkan secara kekeluargaan, berdasarkan atas asas rukun, laras dan patut, apabila penyelesaian demikian berhasil maka akan mempunyai efek yang baik secara sosiologis, psychologis dan yuridis.

Berdasarkan latar belakang tersebut, dapat dirumuskan permasalahan sebagai berikut : 1. Apa yang menjadi penyebab terjadinya sengketa tanah kuburan di Banjar Adat Ambengan dengan Banjar Adat Semana Kecamatan Ubud Kabupaten Gianyar Provinsi Bali?

2. Apa dalam penyelesaian sengketa tanah kuburan menerapkan azas rukun, laras, patut dan siapa saja para pihak yang ikut berperan dalam penyelesaian sengketa tersebut?

\section{METODE PENELITIAN}

Salah satu jenis penelitian kualitatif deskriptif adalah berupa penelitian dengan metode atau pendekatan studi kasus (Case Study). Studi kasus dapat diperoleh dari semua pihak yang bersangkutan dan hasil penelitian ini hanya berlaku pada kasus yang diselidiki. Arikunto mengatakan, bahwa metode studi kasus sebagai salah satu jenis pendekatan deskriptif, adalah penelitian yang dilakukan secara intensif, terperinci dan mendalam terhadap suatu organisme (individu), lembaga atau gejala tertentu dengan daerah atau subjek yang sempit. ${ }^{4}$ Dalam pendekatan kasus dianggap paling relevan untuk menggali secara mendalam/ mengetahui pola penyelesaian sengketa tanah kuburan yang ditempuh para pihak.

\section{PEMBAHASAN}

Setiap organisasi, baik organisasi tradisional maupun organisasi modern yang ada 
hubungannya dengan pengelolaan pemakaman (kuburan umum atau di Bali dikenal dengan nama setra), pasti mempunyai aturan tentang persyaratan pemanfaatan kuburan. Masalah pelarangan penguburan jenasah atau penggalian kembali jenasah yang sudah dikuburkan, terjadi karena beberapa hal, seperti :

1. Masyarakat adat di Bali (warga desa pakraman) belum memahami tujuan (patitis) awig-awig (produk hukum adat) desa pakraman;

2. Yang bersangkutan atau keluarganya telah melakukan pelanggaran awig-awig secara terus-menerus (mamengkung);

3. Yang bersangkutan atau keluarganya tidak memenuhi persyaratan penguburan jenasah seperti diminta atau ditentukan oleh desa pakraman;

4. Masing-masing desa pakraman mempunyai aturan tentang penguburan jenasah, kadangkadang baru dibuat sesudah ada masalah;

5. Kerancuan pemahaman tentang konsep nindihin gumi. $^{5}$

Cara mengatasi masalah :

1. Tujuan dibuatnya awig-awig adalah untuk menciptakan ketertiban dan kedamaian (kasukertan) di desa pakraman. Maka dari itu, kalau ada ketentuan awig-awig yang tidak mencerminkan tujuan, ditinggalkan atau dicabut, diganti dengan ketentuan yang lebih menjamin terciptanya ketertiban dan kedamaian (kasukertan) di desa pakraman;

2. Pelanggaran terhadap awig-awig dapat dilakukan oleh siapa saja. Setiap pelanggaran sebaiknya diselesaikan semasih yang melakukan pelanggaran dapat diajak ngomong (bicara);

3. Tidak masalah desa pakraman membuat aturan atau persyaratan sendiri tentang penguburan jenasah asalkan tidak mengandung muatan "mencekik leher sendiri", tetapi justru memberikan kemudahan kepada warga desa pakraman untuk menguburkan jenasah, walaupun mereka dianggap melakukan pelanggaran adat;

4. Nindihin gumi (membela atau bekerja untuk desa) selama ini diartikan terbatas pada aktivitas atau kegiatan membela atau membangun desa sendiri. Bentuk pembelaan atau pekerjaannya juga terbatas pada fisik (ngayah) dan sumbangan sukarela (dana Punia). ${ }^{6}$

Upaya penyelesaian sengketa tanah kuburan yaitu dengan mengadakan pertemuan berulangkali baik secara bergilir, maupun secara bersama-sama dengan melibatkan pihak ke tiga yaitu Perbekel Sayan, Perbekel Singakerta, Camat Ubud, Kapolsek Ubud, Danramil Ubud, Kapolres Gianyar, Kodim 1616 Gianyar, Bupati Gianyar. Ini mencerminkan ketidak mampuan prajuru banjar (tokoh) adat yang bersangkutan dalam menyelesaikan persoalan intern warganya. Kegagalan tersebut dapat disebabkan karena budaya hukum masyarakat (para pihak) yang bersengketa tidak berkeinginan untuk berdamai. ${ }^{7}$

Akhirnya pada hari Rabu tanggal 13 April 2011 bertempat di Pos Polisi Desa Singakerta dan dilanjutkan kembali di pelataran Pura Prajapati diadakan pertemuan membahas kasus tanah kuburan yang disengketakan antara Banjar Adat Ambengan Desa Pakraman Sayan, Desa Sayan dengan Banjar Adat Semana Desa Pakraman Demayu, Desa Singakerta Kecamatan Ubud.

Kesepakatan tersebut ditandatangani pada tanggal 14 April 2011 oleh Bendesa Adat Sayan, Kelihan Banjar Adat Ambengan, Kelian Banjar Dinas Ambengan, Bendesa Adat Demayu, Kelian Banjar Adat Semana, Kelian Banjar Dinas Semana, pihak-pihak yang hadir sebagai saksi pada saat itu antara lain : Perbekel Sayan, Perbekel Singakerta, Camat Ubud, Kapolsek Ubud, Danramil Ubud, Kapolres Gianyar, Kodim 1616 Gianyar, Bupati Gianyar juga ikut penandatangani kesepakatan tersebut.

Adapun kesepakatan yang telah ditandatangani adalah sebagai berikut:

1. Pihak I (Pertama) dan Pihak II (Kedua) sepakat, lahan kuburan yang terletak di sebelah barat jalan dengan batas pohon celagi ke selatan di bagi sesuai batas dan pembagian yang telah disepakati;

2. Sebagai pembatas untuk lahan kuburan, hasil dari pada pembagian sebagaimana dimaksud 
pada poin 1 (satu) kesepakatan ini adalah menggunakan batas buatan (tembok) pembuatannya dibantu oleh Pemerintah Kabupaten Gianyar;

3. Lahan kuburan bagian dari pihak I (Pertama) dengan status pemanfaatan, bukan berstatus kepemilikan dan juga bukan sebagai batas wilayah kedinasan;

4. Mengenai batas wilayah kedinasan akan ditentukan oleh Pemerintah Derah Kabupaten Gianyar sesuai dengan perundang-undangan yang berlaku;

5. Pelinggih Pura Prajapati dan jalan yang ada sekarang tetap digunakan bersama-sama oleh kedua belah pihak;

6. Pihak I (Pertama) dan pihak II (Kedua) tetap menjalin hubungan yang harmonis dan bila ada kematian tetap berkoordinasi dan menghormati dresta (pedoman) yang berlaku di masingmasing Banjar Adat.

Sebenarnya konflik sudah ada sepanjang sejarah dan menjadi bagian serta dinamika dalam kehidupan. Konflik itu sendiri ada yang bersifat positif(fungsional) ada juga konflik yang bersifat negatif(disfungsional). Disatu sisi konflik dapat menimbulkan terjadinya perubahan sosial, di pihak lain konflik juga dapat terjadi sebagai akibat suatu perubahan sosial. $^{8}$

Perubahan dan perkembangan dalam suatu masyarakat di manapun di dunia ini merupakan gejala normal, hal ini merupakan konsekuensi dari akibat lajunya arus globalisasi terutama kemajuan dalam bidang ilmu pengetahuan dan teknologi. Soerjono Soekanto mengatakan bahwa ada 3 (tiga) teori umum perihal perubahanperubahan sosial yang berhubungan dengan hukum yakni, pertama : komunikasi yang progresif dari penemuan-penemuan di bidang teknologi, kedua : kontak dan konflik antara kebudayaan, ketiga : terjadinya gerakan sosial (social movement). ${ }^{9}$

Setiap gejala dipandang sebagai suatu unsur yang merupakan bagian daripada keseluruhan proses yang dinamis, gejala sosial dianggap sebagai suatu unsur keseluruhan. Dengan demikian, maka setiap gejala sosial dianggap sebagai bagian daripada jaringan kejadian- kejadian atau peristiwa-peristiwa, struktur-struktur dan proses-proses yang mendasarinya. Tentang konflik, maka terdapat dua model dari masyarakat yang masing-masing disebut sebagai model konflik dan model konsensus. Cici-ciri kedua model tersebut adalah :

1. Ciri-ciri model konsensus adalah:

a. Masyarakat mempunyai struktur sosial yang stabil dan secara relatif kokoh;

b. Terintegrasi secara baik;

c. Setiap elemen berfungsi dan mendukung pemeliharaan sistem;

d. Struktur sosial didasarkan pada suatu konsensus tentang nilai-nilai.

2. Ciri-ciri model konflik adalah :

a. Setiap bagian masyarakat dapat berubah;

b. Pada setiap bagian masyarakat terdapat konflik atau dissensus;

c. Setiap elemen mendorong terjadinya perubahan;

d. Didasarkan pada paksaan yang dilakukan oleh sebagian dari warga masyarakat. ${ }^{10}$

Berdasarkan uraian diatas dapat disimpulkan bahwa sengketa tanah kuburan yang terjadi di Kabupaten Gianyar, akan menyebabkan perubahan sosial dan menimbulkan perpecahan. Sebaliknya apabila sengketa tanah kuburan ditinjau dari azas yang terdapat dalam hukum adat khususnya azas rukun, laras dan patut dapat diimplementasikan dengan baik melalui proses mediasi, walaupun sebelumnya kedua belah pihak bersikukuh dengan keyakinannya masing-masing bahwa "kamilah yang paling benar/paling berhak".

Terkait penyelesaian sengketa tanah kuburan antara Banjar Adat Ambengan dengan Banjar Adat Semana, jika dikaji dari pendekatan asas-asas hukum adat dapat diuraikan sebagai berikut :

1. Asas rukun adalah pedoman dalam menyelesaikan konflik adat. Asas rukun berhubungan erat dengan pandangan dan sikap seseorang menghadapi hidup bersama di dalam suatu lingkungan dengan sesamanya, untuk mencapai suatu suasana hidup yang aman, tenteram, dan sejahtera. ${ }^{11}$ Penyelesaikan konflik adat yang menggunakan asas rukun dimaksudkan 
untuk mengembalikan keadaan kehidupan seperti keadaan semula. Asas rukun tidak menekankan menang kalah pada salah satu pihak, melainkan terwujudnya kembali keseimbangan yang terganggu, sehingga para pihak yang bertikai bersatu kembali dalam ikatan desa adat. ${ }^{12}$

2. Asas patut adalah menunjuk kepada alam kesusilaan dan akal sehat, yang ditujukan kepada penilaian atas suatu kejadian sebagai perbuatan manusia maupun keadaan. Patut pada satu sisi berada dalam lingkungan alam normatif, sedangkan pada sisi lain berada dalam kenyataan. Patut berisi unsur-unsur yang berasal dari alam susila, yaitu nilai-nilai buruk atau baik dan unsur akal sehat, yaituperhitungan-perhitungan yang menuruthukum dapat diterima. ${ }^{13}$ Asas kepatutan digunakan untuk mencari jawaban atas suatu persoalandengan menekankan pada upaya bagaimana kualitas dan status para pihak yang berselisih dapat diselamatkan, artinya para pihak tidak sampai mendapat rasa malu. Dengan kata lain perasaan seseorang benar-benar dijaga. ${ }^{14}$

3. Asas laras adalah penggunaan asas keselarasan dilakukan dengan memperhatikan tempat, waktu dan keadaan (desa, kala, patra). Asas laras dalam hukum adat digunakan dalam menyelesaikan konflik adat yang konkret dengan bijaksana, sehingga putusan terhadap konflik adat diterima oleh para pihak yang bersangkutan dan masyarakat adat merasa puas. ${ }^{15}$

Dengan demikian upaya mediasi dengan mengedepankan azas rukun, laras dan patut secara terus menerus dapat menumbuhkan kesadaran para pihak supaya sengketa tanah kuburan yang terjadi di Kabupaten Gianyar tidak berkepanjangan yang pada akhirnya kedua belah pihak sepakat menandatangani surat kesepakatan penyelesaian kasus tanah kuburan pada tanggal 14 April 2011.

Pola penanganan sengketa adat di Kabupaten Gianyar memang telah pula terpola sedemikian rupa yang mana mengutamakan koesistensi damai, sebagaimana dicatat dalam laporan penanganan sengketa adat di Kabupaten
Gianyar yang dirangkum oleh Kantor Kesbang Pol dan Linmas Kabupaten Gianyar Tahun 2012. Dalam penanganan konflik sosial Pemda Kabupaten Gianyar bekerjasama dengan Polres Kabupaten Gianyar dan Instansi terkait dengan selalu mengedepankan pola penyelesaian antara lain:

1. Koeksistensi damai, yaitu mengendalikan konflik dengan cara tidak saling mengganggu dan saling merugikan, dengan menetapkan peraturan yang mengacu pada perdamaian serta diterapkan secara ketat dan konsekuen;

2. Mediasi (perantaraan), jika penyelesaian konflik menemui jalan buntu, masing-maing pihak bisa menunjuk pihak ketiga untuk menjadi perantara yang berperan secara jujur dan adil serta tidak memihak;

3. Tujuan sekutu besar, yaitu dengan melibatkan pihak-pihak yang berkonflik ke arah tujuan yang lebih besar dan kompleks;

4. Tawar-menawar integratif, yaitu dengan menggiring pihak-pihak yang berkonflik, untuk lebih berkonsentrasi pada kepentingan luas/ umum, dan tidak hanya berkisar pada kepentingan sempit/pribadi.

Terwujudnya penyelesaian konflik tersebut berkat kerjasama yang baik antar pemimpin daerah, instansi terkait serta berkat partisipasi masyarakat Kabupaten Gianyar. Namun kecenderungan perubahan di masyarakat kini menunjukkan bahwa sikap, prilaku maupun moral orang Bali sudah mulai terdegradasi yang melekat pada setiap individu karena berbagai faktor, dan setiap unsur dalam masyarakat memberikan sumbangan untuk terjadinya disintegrasi dalam wujud konflik. Ini menunjukkan bahwa sengketa kuburan antara warga Banjar Adat Ambengan dan warga Banjar Adat Semana terjadi karena adanya gangguan atas keseimbangan dalam pergaulan hidup bermasyarakat.

Berkaitan dengan mewujudkan harmonisasi dalam kehidupan masyarakat adat, menurut Moh.Koesnoe, dalam penerapan penyelesaian perkara, berpijak pada sistem adat dan hukum dari pandangan dan ajaran tentang 
manusia dan kehidupan yang merupakan kategori konstitutif yang terdiri dari tiga macam azas kerja yaitu kerukunan, kepatutan, dan keselarasan untuk dapat mencapai kehidupan bermasyarakat yang tenang, tentram dan sejahtera dalam ikatan kekeluargaan, yang ke tiga azas tersebut tidak dapat dipisahkan satu sama lain baik dalam proses, maupun dalam soal-soal materiil. ${ }^{16}$

\section{PENUTUP}

1. Penyebab terjadinya sengketa tanah kuburan, berawal dari pemotongan 3 (tiga) pohon kelapa dan 1 (satu) pohon blalu yang rencananya akan digunakan untuk pembangunan Pura Prajapati. Dengan pemotongan pohon tersebut maka terjadilah sengketa antar dua banjar adat dengan adanya saling klaim kepemilikan tanah kuburan. Dengan demikian maka terjadilah sengketa berkepanjangan dan berujung pada pelarangan penguburan jenasah.

2. Dalam kaitan sengketa adat, desa pakraman di Bali merupakan organisasi tradisional yang memiliki fungsi strategis mewujudkan harmonisasi kehidupan masyarakat Bali. Caranya sesuai dinamika yang kini terjadi adalah melalui revisi awig-awig (produk hukum adat) sehingga dapat meminimalisir terjadinya sengketa/konflik yang berkepanjangan dan, dalam penyelesaian sengketa mengedepankan azas rukun, laras dan patut dengan tidak mengutamakan menang atau kalah tetapi yang diutamakan adalah win-win solusion sehingga terwujud keseimbangan dan keharmonisan dalam kehidupan bermasyarakat.

\section{DAFTAR PUSTAKA}

\section{A. Buku :}

Abdul Manan, 2009, Aspek-Aspek Pengubah Hukum, Jakarta, Kencana, Cetakan Ketiga.

Herowati Poesoko, M.Khoidin, Dominikus Rato, 2014, Eksistensi Pengadilan A d a $t$ Dalam Sistem Peradilan di Indonesia, LaksBang Justitia, Surabaya.
I Nyoman Sirtha, 2008, Aspek Hukum Dalam

Konflik Adat di Bali, Udayana

University Press, Cetakan Pertama.

Joni Emirzon, 2001, Alternatif Penyelesaian

Sengketa Di Luar Pengadilan

(Negosiasi, Mediasi, Konsiliasi dan

Arbitrase), PT.Gramedia Pustaka

Utama, Jakarta.

Ronny Hanitijo Soemitro, 1981, Pendekatan

Konflik Terhadap Masalah-

Masalah Hukum, dalam satjipto

Rahardjo, Hukum Dalam Perspektif

Sosial, Alumni, Bandung.

Soerjono Soekanto, 2009, Sosiologi Suatu

Pengantar, PT.Raja Grafindo Persada,

Jakarta.

1981, Fungsi

Hukum dan Perubahan Sosial, Alumni, Bandung.

TIP.Astiti, 2010, Desa Adat Menggugat dan

Digugat, Udayana University Pres,

Cetakan Pertama.

Wayan P.Windia, 2014, Hukum Adat Bali

Aneka Kasus \& Penyelesaiannya,

Udayana University Press, Cetakan

Pertama.

Herowaati Poesoko, M.Khoidin. Dominikus Rato,

2014, Eksistensi Pengadilan A d a $t$

Dalam Sistem Peradilan di Indonesia,

LaksBang Justitia, Surabaya.

\section{B. Laporan Penelitian :}

Pemda Kabupaten Gianyar, 2012, Laporan

Penanganan Konflik Sosial di

Kabupaten Gianyar Tahun 2007-2011.

Kesbang Pol dan Linmas, 2012, Laporan Kasus

Adat/Tapal Batas Desa Yang Masih

Berkembang Yang Perlu Diwaspadai

Untuk Tahun 2012 Di W i l a y a h

Kabupaten Gianyar.

TIP. Astiti,et.al., 2012, Sengketa Tanah Adat

Yang Disertai Kekerasan Dalam

Konteks Perkembangan Pariwisata, (laporan Penelitian Magister

Kenotariatan Universitas Udayana Tahun 2012). 
C. Internet :

Pendekatan Studi Kasus (Case Study) Dalam Penelitian kualitatif, $\quad \underline{\boldsymbol{h} t \boldsymbol{t}} \boldsymbol{\mathrm { e }}: / /$ www.menulis proposalpenelitian.com/ 2011/01/pendekatan-studi- kasuscase-study-dalam.html, diakses hari minggu tanggal 18 Januari2019.

\section{(Footnotes)}

${ }^{1}$ Soerjono Soekanto, 2009, Sosiologi Suatu Pengantar, PT.Raja Grafindo Persada, Jakarta, h.280.

${ }^{2}$ Joni Emirzon, 2001, Alternatif Penyelesaian Sengketa Di Luar Pengadilan (Negosiasi, Mediasi, Konsiliasi dan Arbitrase), PT.Gramedia Pustaka Utama, Jakarta, h.21.

${ }^{3}$ Ronny Hanitijo Soemitro, 1981, Pendekatan Konflik Terhadap Masalah-Masalah Hukum, dalam satjipto Rahardjo, Hukum Dalam Perspektif Sosial, Alumni, Bandung, h.9.

${ }^{4}$ Pendekatan Studi Kasus (Case Study) Dalam Penelitian kualitatif, http://www. menulisproposalpenelitian.com/2011/ 01/pendekatan-studi-kasus-case-studydalam.html, diakses hari minggu tanggal 18 Januari 2019.

${ }^{5}$ Wayan P.Windia, 2014, Hukum Adat Bali Aneka Kasus \& Penyelesaiannya, Udayana University Press, Cetakan Pertama, h.154.
${ }^{6}$ Ibid, h.156.

${ }^{7}$ TIP. Astiti, et.al., 2012, Sengketa Tanah Adat Yang Disertai Kekerasan Dalam Konteks Perkembangan Pariwisata, (laporan Penelitian Magister Kenotariatan Universitas Udayana Tahun 2012), h.4.

${ }^{8}$ TIP.Astiti, 2010, Desa Adat Menggugat dan Digugat, Udayana University Pres, Cetakan Pertama, h.53.

${ }^{9}$ Abdul Manan, 2009, Aspek-Aspek Pengubah Hukum, Jakarta, Kencana, Cetakan Ketiga, h.76-77.

${ }^{10}$ Soerjono Soekanto, 1981, Fungsi Hukum dan Perubahan Sosial, Alumni, Bandung, h.55.

${ }_{11}^{1}$ TIP.Astiti, Op.Cit, h.76-77.

${ }^{12}$ I Nyoman Sirtha, 2008, Aspek Hukum Dalam Konflik Adat di Bali, Udayana University Press, Cetakan Pertama, h.79.

${ }^{13}$ Ibid, h.80.

${ }^{14}$ TIP.Astiti, Op.Cit, h.77.

${ }^{15}$ I Nyoman Sirtha, Op.Cit, h.81.

${ }^{16}$ Herowaati Poesoko, M.Khoidin. Dominikus Rato, 2014, Eksistensi Pengadilan Adat Dalam Sistem Peradilan di Indonesia, LaksBang Justitia, Surabaya, h.22. 